\title{
COLUMN
}

\section{The Tooth of Time: Conrad Gebelein}

\author{
Paul F. Hoffman \\ 1216 Montrose Ave. \\ Victoria, BC, Canada, V8T 2K4
}

I had been in Baltimore less than a week, long enough to be asked to leave the home of my foreign-student host (for suggesting that some good might come from the Cuban Revolution and that not all the bad could be blamed on Fidel Castro). The eviction proved to be of little inconvenience: in the low-occupancy zone a few blocks south of the university, where urban white "BALL-mer" met inner-city black "Bal-TEE-more", they would rent to anyone. Eager to get running again after the field season, I had signed up for a locker at Homewood Field, the Johns Hopkins University lacrosse and football stadium. The varsity cross-country squad was going out for a "long" run, so I decided to join them to learn a route. With conceit, I noted that they did nothing without explicit instructions from a coach: at McMaster University, Ron Wallingford (3rd in the Boston marathon the year I graduated) had encouraged us to train independently, each according to their academic schedule. We had feasted on cross-border competition and were CIAU champions the previous Fall. The run took us on a flat loop around the industrial east side of Baltimore, an old port city at the head of Chesapeake Bay where "the rocket's red glare" and "bombs bursting in air" memorialize the Colonies' war over taxes. Accustomed to the Niagara Escarpment in Hamilton, I chafed at the pace and when, after less than an hour, the team turned back toward Homewood Field, I moved up to signal that I was going around again. To emphasize the point, I took off at a serious clip before turning hard right to repeat the loop. After 10 minutes of solitude, I was startled by what sounded like footfalls not my own. I doubted that any of the varsity squad had followed me, let along caught up, but without turning I knew there was someone on my tail. Sensing his presence was known, the mystery runner came up alongside, looked over, and grinned. His thick neck and sloping shoulders were those of an athlete; the clipped stride was all runner. Longjawed, with a broad freckled forehead and reddish hair, already in retreat, his small mouth bore a trumpet player's distinctive callouses. We finished the loop, first one leading and then the other, before introducing ourselves by name after returning to Homewood Field. Conrad D. (Connie) Gebelein, was a Baltimore native who had captained the varsity cross-country and track teams before graduating the previous Spring in biology and biochemistry. He was staying on at Hopkins to do graduate work in oceanography, a strong department linked with the Chesapeake Bay Institute (since dissolved). Conrad had the idea, uncommon in 1964, that microbes were grossly understudied relative to their importance in the balance of marine life. He thought that microbial mats in coastal settings were a good place to start because high cell densities were accessible without the need of a research vessel.

Gebelein had deep Hopkins connections, but not in science. I never met his father, Conrad G. Gebelein, a musician-in-residence, but his grandfather was a Hopkins institution. Conrad Gebelein Sr was born in 1894 in northern Bavaria, close to Nüremburg, one of ten children of a produce broker. At nine, he began music lessons paid for by working in an instrument repair shop. As a teenager, he emigrated with a sister to Baltimore, where he worked in a foundry, played in dance bands, and eventually graduated in music from the Peabody Conservatory. He was the first musician to perform live on WBAL-AM radio and in 1924 he founded the BMO, Baltimore Mandolin Orchestra. As composer, arranger, conductor, music director and featured soloist - on banjo and Hawaiian guitar- "Gebby" Gebelein's 19piece ensemble, plus a featured banjo quartet, nearly doubled in size during its five-year existence, cut short by the Great Depression. The mandolin family of instruments covers the full tonal range of a bowed-string orchestra, permitting voiceings that are impossible for a guitar ensemble. The popularity of Hawaiian-style guitar in the early 20th century lives on in the pedal-steel guitar of country \& western music, the slide guitar of the blues, and the legacy of Jimi Hendrix. Gebelein revived the BMO in 1938, only to be cut down again when the U.S. entered WW-II. The present $\mathrm{BMO}$, a thriving and viable orchestra, was reconstituted in 1975 and directed by Gebelein until a year before his death at 86 in 1981. During his long life, he taught music at many prestigious Baltimore prep 
schools, had a financially successful private teaching practice, and was the instrumental and vocal music director and adored band leader at Johns Hopkins for 50 years. In 1967, I joined the throng attending the official naming of the main grandstand at Homewood Field, the "Yankee Stadium of Lacrosse", in his honour.

Events during our first year in grad school caused our interests to converge beyond running and music. After the 1965 field season with John McGlynn, southeast of Great Slave Lake, GSC gave me some days of helicopter time to conduct a feasibility check of my proposed thesis project on early Paleoproterozoic (Orosirian) stratigraphy and paleocurrents. Fluvial clastics were the primary targets for paleocurrent work, but I had been deeply impressed on Appalachian field trips by the exquisite presentation of sedimentary structures in natural outcrops (cow pastures) of early Paleozoic carbonates. Sedimentology was in the process of rediscovering sedimentary structures and outcrops after decades of catering to the petroleum industry's need for analysis of drill-cores and cuttings. Carbonates are intrinsically more informative than clastic sediments because they are products of biological, physical and chemical processes combined, resulting in a distinct carbonate record for every geological period. For months, I had wondered if the nearly two-billion-year-old carbonates in the east arm fold belt of Great Slave Lake would preserve primary structures. Now I was about to find out. "Algal structures" were reported on the gently-dipping north side of the fold belt (Lausen 1929; Stockwell 1932) and the east end of Blanchet Island was singled out for good exposure in the marginal notes on Stockwell's map (Stockwell 1936). As the pilot circled for a landing I began to see them, regularly-spaced columns, reef-like clusters, here in oblique cross-section, there on a glaciated bedding plane, occasionally in synoptic growth morphology. When the blades stopped, I was out and running through the thin bush shouting, "They're everywhere!" The pilot later said he feared he might have to fly to Snowdrift and fetch the Constable.

Analogous structures (Fig. 1)

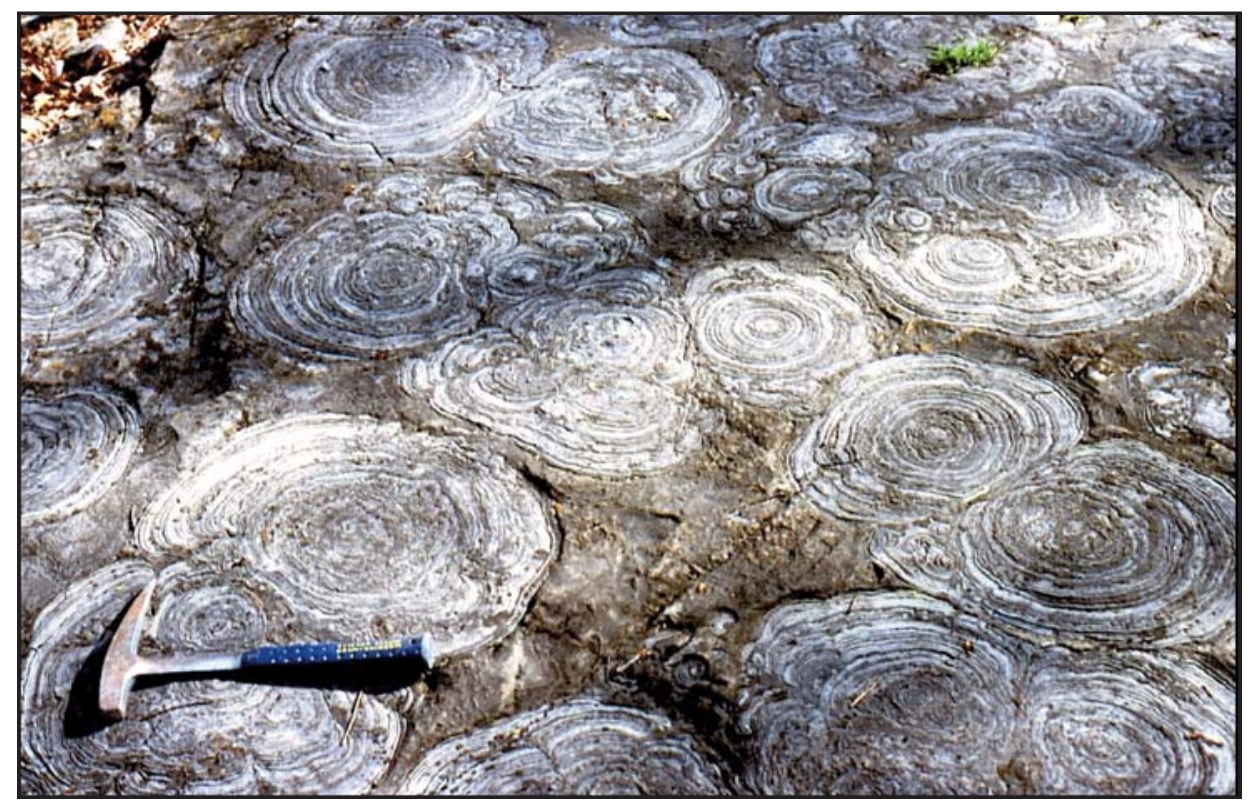

Figure 1. Cryptozoön proliferum (Hall 1883), low-relief columnar stromatolites in the Hoyt limestone (Furongian), exposed on a glaciated bedding-plane $\left(43^{\circ} 05^{\prime} 32.5^{\prime} \mathrm{N}\right.$, $73^{\circ} 50^{\prime} 54^{\prime \prime} \mathrm{W}$ ) near Saratoga Springs, New York. 500 million years ago, Laurentia was encircled by vast areas of shallow-water carbonate sediments.

were first described and named, Cryptozoon proliferum, in the Hoyt limestone (Furongian) near Saratoga Springs in upstate New York (Hall 1883).

Although well-laminated, the structures proved to lack cellular preservation and the study of crudely similar laminated encrustations in modern freshwater lakes and rivers led to their interpretation as tufa-like precipitates, induced by vital processes $\left(\mathrm{CO}_{2}\right.$ consumption) of "blue-green algae" (Walcott 1914; Roddy 1915; Bradley 1929), which were reclassified as cyanobacteria in the 1980's. Walcott, discoverer of the Burgess Shale fauna in 1909, inferred that the Cambrian "explosion" was not an explosive radiation at all, but simply an expression of the first marine transgression of the continents (Walcott 1914). He pointed to the abundance of stromatolites in the Belt-Purcell and other "Algonkian" (Proterozoic) carbonates as evidence that pre-Cambrian epicontinental basins were non-marine and thereby incapable of recording a gradual emergence of animal life in the (permanent) ocean. However in Europe, where the term "stromatolite" (Kalkowsky 1908) was introduced for benthic (attached) laminated structures of microbial origin (Riding 1999), Triassic examples occur in marine as well as terrestrial formations.
The epic investigation of Andros Island (Great Bahama Bank) by Maurice Black of Cambridge University in 1930, part of Richard M. Field's visionary geological oceanography mega-project, confirmed that modern stromatolites grow under the influence of biologically heterogeneous mats of "blue-green algae", in conditions ranging from seasonally fresh to fully marine, and that growth in marine waters is dominated by entrapment of pre-existing grains, rather than by in situ carbonate precipitation (Black 1933). In the 1960 's, interest in stromatolites was re-energized by the discovery of impressive Holocene examples in Shark Bay, a hypersaline embayment in Western Australia, which were inferred to be diagnostic of the intertidal zone (Logan 1961; Logan et al. 1964). Geologists were quick to adopt a paleoenvironmental diagnostic. Yet, as Conrad pointed out at Friday beer hour, no controlled experiment had been conducted to prove that living cells were responsible for stromatolite growth, not the mere presence of copious, mucilagenous, extracellular, sheath material. Nor, I chimed in, had the growth rate or the temporal significance of the characteristic lamination been measured in any actively growing stromatolite. 
Fortuitously, carbonate sedimentologist Bob Ginsburg (formerly with Shell Development Company, the research arm of Shell Oil, in Coral Gables, Florida) was appointed to a joint professorship in geology and oceanography at Hopkins in 1965 (Pettijohn 1988). With him came the knowledge (Ginsburg 1955) that modern stromatolites, like those studied by Maurice Black in the Bahamas, could also be found in south Florida (Fig. 2). With him as well came the ability to convince a biologist-biochemist like Conrad that the paramount significance of microbially mediated sedimentary processes was geological. Conrad's thesis on "Dynamics of Recent carbonate sedimentation and ecology" (Gebelein 1977) focused on Cape Sable (Fig. 3), the south-west tip of mainland Florida, deep in the Everglades. There, a formerly brackish to freshwater lake and complex of ponds are protected from the sea by barrier beaches. When mapped by the US Coast Survey a few years before the American Civil War, the lake (now Lake Ingraham, unchanged in outline) was "ankle-deep in winter but over six feet deep in summer, and connected to all the ponds by trails worn by the alligators in their migrations" (Dorr 1857). The only outlet to the sea was northward through Little Sable Creek. In the early 1900's, hundreds of drainage canals were cut all across the state for land development, lowering the freshwater table by up to 2 meters and diverting runoff away from Cape Sable. In 1922-26, canals were cut at both ends of Lake Ingraham (Fig. 3) by the Model Land Company, exposing the lake and connected ponds to open marine, tidal conditions (Tebeau 1968). "The opening of the canals brought about a marked change in sedimentation style and rate. This change is clearly recorded in the sediments and provides a baseline from which calculations of thicknesses and rates of deposition under the present marine regime can be made" (Gebelein 1977).

Following the stromatolite extravaganza in Great Slave Lake, I took a bus from Calgary to Laramie (Wyoming) and hitch-hiked to the Grand Tetons in hopes of meeting up with Baltimore apartment mate Pete Geiser and his climbing associates. Unable to find them, I bought an

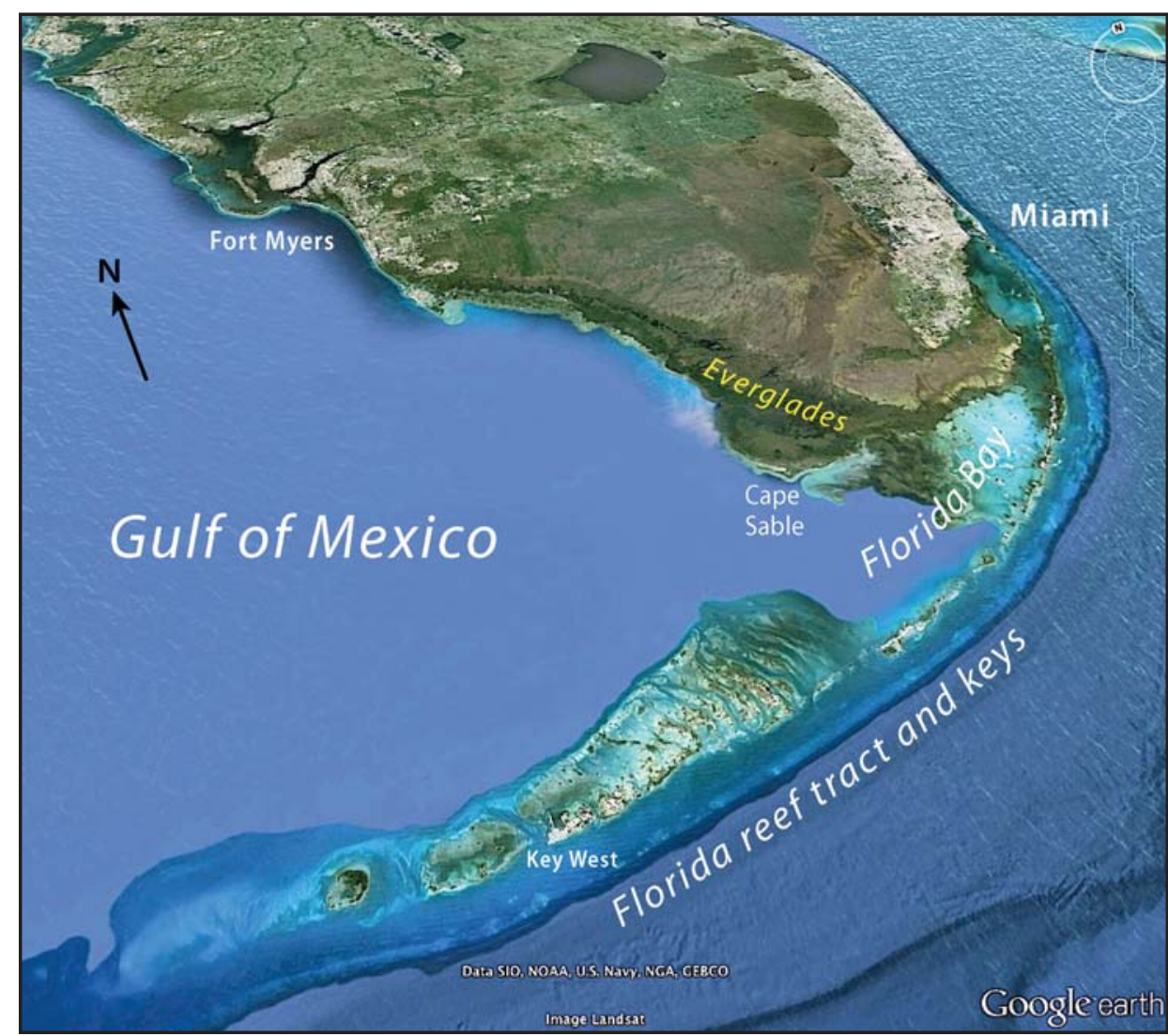

Figure 2. Oblique satellite image of south Florida, showing Conrad Gebelein's thesis area at Cape Sable in relation to the Everglades and Florida Bay. Florida Straits and Great Bahama Bank lie to the right out of view. The middleground is $\sim 200$ $\mathrm{km}$ wide.

International Scout $(4 \mathrm{x} 4)$ in Green River and spent two glorious weeks touring Wyoming and Utah geology until a September snowstorm in the Wind River Range chased me back to Baltimore. Thanks to the vehicle, I became Conrad's first field assistant at Cape Sable. Oceanographers carry more gear than geologists and the truck was crammed with sediment traps, current velocity meters, leveling rods, boxes and tubes of all sizes for sediment coring, and endless samples bags and bottles of various liquids and powders. There was barely room for our personal gear, Conrad's trumpet case, an alto sax I picked up at a pawn shop, two lacrosse sticks and a bag of balls. Field work with Conrad was lots of fun. At Cape Sable, we confirmed Ginsburg's observation that uncemented proto-stromatolites, composed of particulate carbonate mud trapped by microbial mats, occur on the cut banks of levees along the tidal channels of Lake Ingraham. Their immediate location was not propitious for immortality in the stratigraphic record. However, fields of laminated proto-stromatolites the size of cow flaps occur around the margins of the many ponds adjacent to Lake Ingraham, where microbial mats colonize desiccation polygons (Figs. 4, $5)$.

As a geologist used to passive objects of study, Conrad's ingenuity in making measurements (all manual) and conducting controlled experiments in the field was an eye-opener. Current velocities, for instance, were measured by timing the travel of a black mangrove pneumatophore, which floats below the surface, unaffected by wind, but shallow enough to be seen. There were many experiments, but the ones most interesting to me concerned stromatolite accretion rates. Conrad staked scores of square-meter size plots on microbial surfaces at different levels (flooding frequencies) and flow regimes. He sprinkled non-toxic iron oxide paint pigment on the surface of each plot, lightly so as not to impede microbial growth, but enough to iden- 


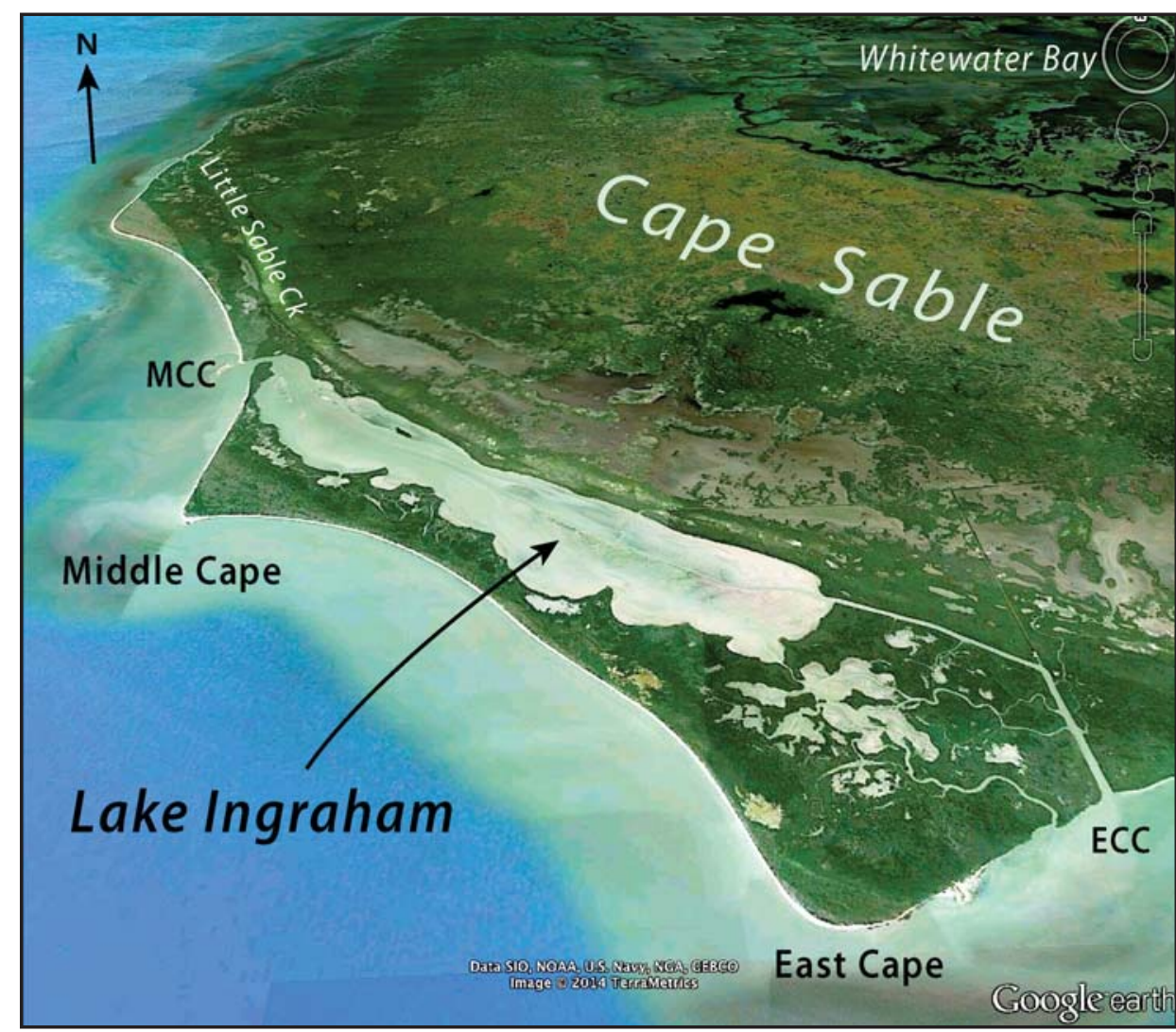

Figure 3. Oblique satellite image of Cape Sable at the southwest tip of mainland Florida. Lake Ingraham, a former freshwater lake, as well as adjacent ponds, became fully marine tidal environments after the East Cape and Middle Cape canals (ECC and MCC) were cut in 1922-26. Before that time, Lake Ingraham drained northward through Little Sable Creek. The Flamingo Lounge lies to the right out of view. The middleground is $\sim 30 \mathrm{~km}$ wide.

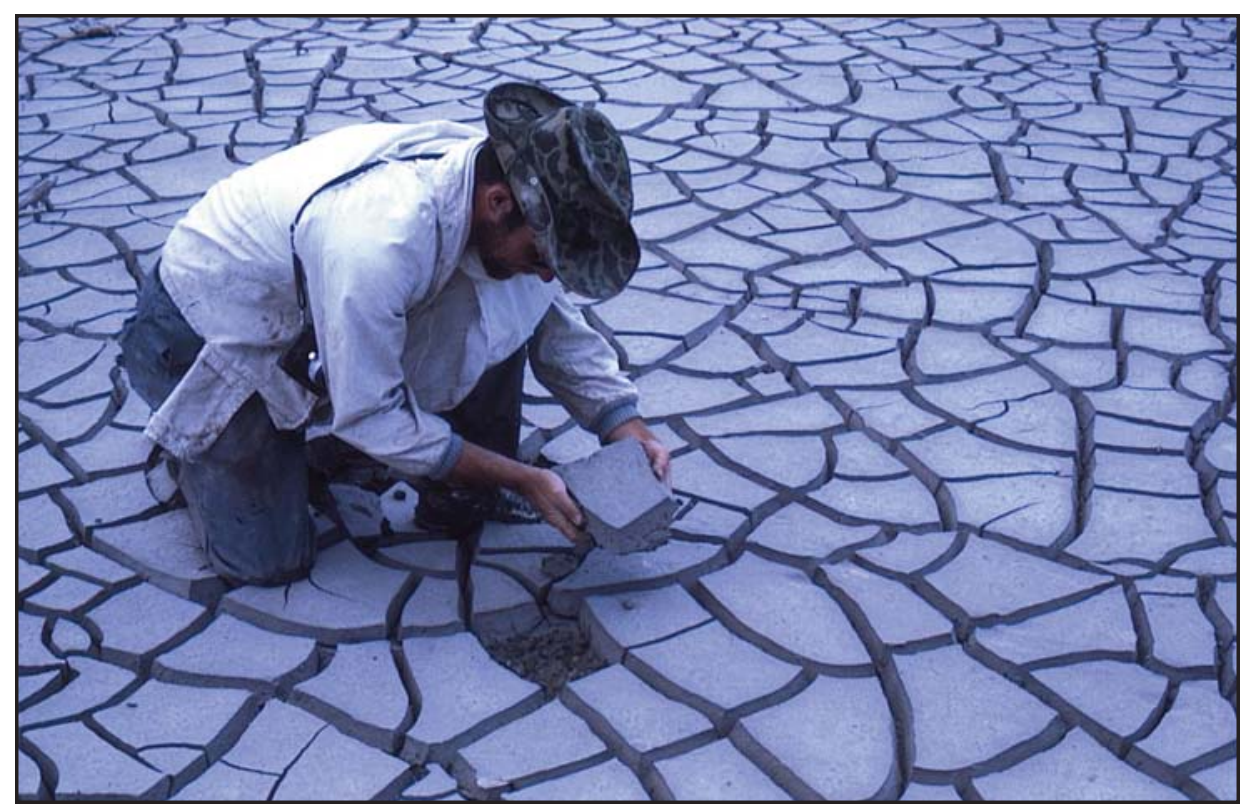

Figure 4. Conrad Gebelein at Cape Sable in early 1967, examining desiccation polygons in marine aragonitic pelleted mud, deposited in the rarely-exposed central part of a large pond near Lake Ingraham. The following year, the cracks had healed without a trace (Gebelein 1977). tify the horizon later in a core. At most sites there were two plots, one for control and one in which the mats were killed without mechanical disruption by emersion in concentrated formalin. The plots were revisited and cored, weekly, monthly or seasonally as appropriate. As a back-up, and out of impatience, we measured accretion rates in the field by simply cutting the sediment with a knife.

Given short winter days and the transit time in a skiff from our campsite on the marl prairie, it was nearly two weeks before we had time to revisit the first of the sedimentation rate experiment sites. "Yes!", shouted Conrad as the skiff felt bottom. The pigment could still be seen at the poisoned plots-excepting those at highvelocity locations where the pigment was moved by currents-but the controls were covered by new sediment. We soon had field data from a sufficient vertical range to show that individual sediment laminae $(\sim 0.5-\mathrm{mm}$ light-dark couplets) within the matbound structures corresponded roughly with submergence events during high tides. But when Conrad compared our field data with the USGS tide tables for the East Cape Canal (Fig. 3), two new relations emerged. First, each semi-diurnal submergence was recorded (depending on elevation) only if some part of the submergence occurred in daylight. Strictly nocturnal submergences went unrecorded. Second, the thickness of the sediment-rich laminae at any given site correlated roughly with the duration of submergence during daylight hours. I was dumbfounded. We had ourselves a coupled record of diurnal and tidal forcings. "Biology can do anything," said Conrad, one of his favourite expressions. We had a couple of extra rounds that night at the Flamingo Lounge. Walking back to camp afterwards under moonlight, we dared to dream of a Precambrian record of planetary spin-reduction and lunar retreat, modulated by time-dependent tidal friction, constrained by data from stromatolite laminology (Pannella 1972; see also Jones 1981).

The next morning over breakfast and many glasses of orange juice, nocturnal processing revealed a problem with our sedimentation rates. If 


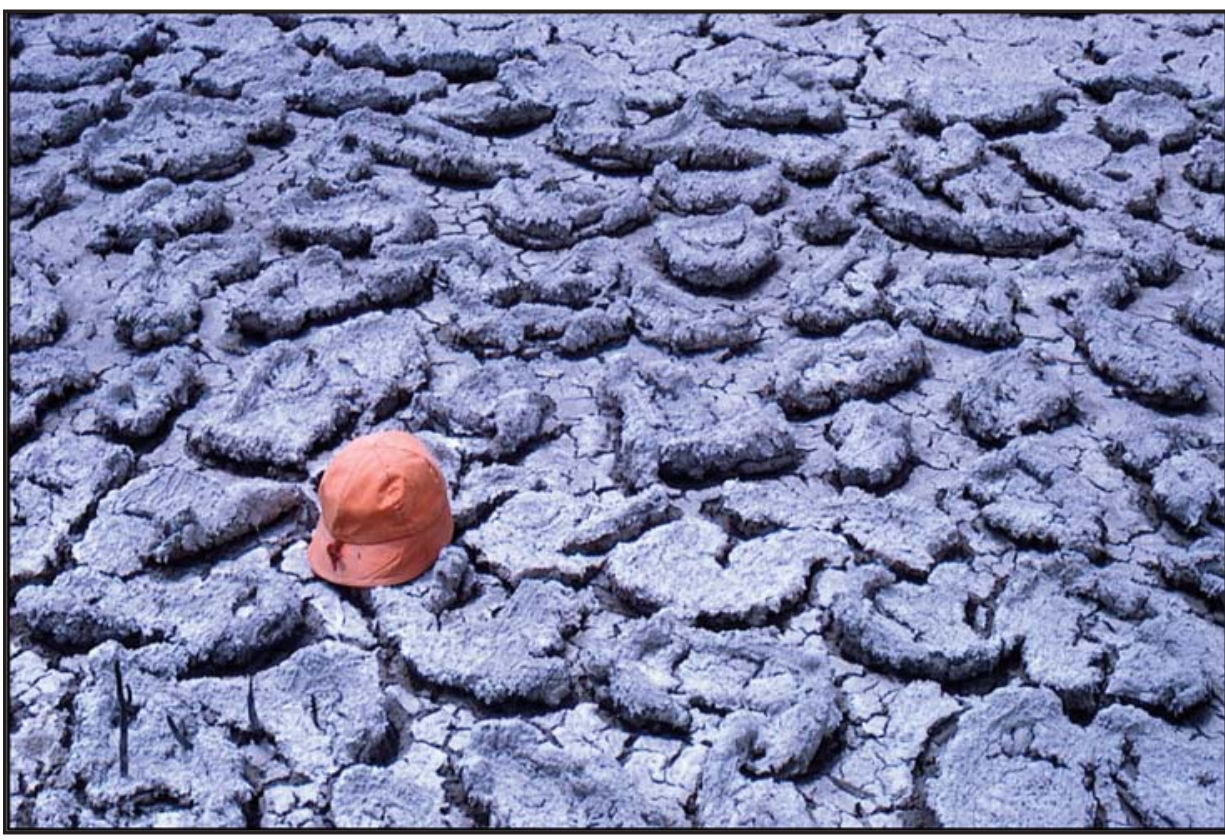

Figure 5. "Cow-flap" stromatolites formed where microbial mats colonized desiccation polygons at the margin of a pond adjacent to Lake Ingraham, Cape Sable. Hat for scale. The calyx-like structures are internally laminated and consist of microbially-bound marine pellet-mud. The structures are flooded only at high tides, unlike the mat-free polygons in the center of the pond (Fig. 4), which are rarely exposed.

true, they implied that the total thickness of microbially laminated mud accumulated since $1922-26(\sim 0.3 \mathrm{~m})$ represents only a few months of accretion. Stumped, we continued collecting data. During his second field season at Cape Sable, Conrad stayed on past the equinoctial start of the rainy season. Caught on an exposed mud flat during a heavy rainstorm, he was unsettled to see the proto-stromatolites being actively eroded. The mucilagenous sheath material, so efficient at trapping and binding particulate grains borne by tidal currents, was vulnerable to mechanical attack by wind-driven raindrops. Evidently, the microbially-laminated mud unit, including the protostromatolites, accretes every winter during the dry season and degrades in summers when it pours every afternoon. Uninterrupted lengthy time series of Precambrian intertidal stromatolites looked like a long-shot.

The reason Conrad stayed late at the Cape was that in February (1967), Ginsburg had convened a conference at Hopkins on algal stromatolites. Among the invited speakers were Steve Golubiç (Boston) on freshwater microbial carbonates, Claude Monty
(Liège) on the Bahamian microbial structures, David Kinsman and Chris Kendall (London) on the coastal sabkhas and microbial mats on the Trucial Coast of the Persian Gulf, and Brian Logan (Perth) on the modern stromatolites in Shark Bay, Western Australia. As a result of the conference, I would visit each of these areas the following year. At the conference, I had presented results from my first full field season in Great Slave Lake. With assistants Tom Tourek (Hopkins) and Wayne Shepheard (Calgary), we had measured the orientations of elongate stromatolites (Fig. 6) and current-related structures in hundreds of beds of the Pethei Group, which is exposed for $\sim 160 \mathrm{~km}$ along strike and undergoes a major shelf-to-basin facies change across the narrow fold belt (Hoffman 1974, 1989). We found that elongate stromatolites are oriented parallel to paleocurrents and perpendicular to the major facies zones. Furthermore, they are consistently oversteepened in the off-shore direction, due to excess accretion toward the source of carbonate sediment. Stromatolite shape and orientation offered a simple means of determining shoreline orientations and facing-directions in ancient carbonate sequences, not a trivial aid in Precambrian shields where structural basins of preservation cannot be assumed to mimic depositional basins. Logan button-holed me after my talk and said I needed to come to Shark Bay (Fig. 7). Buoyed by the conference, I immediately finalized and submitted my first ever paper (Hoffman 1967)_Conrad having already published, on cyanobacterial pigmentation, as an undergraduate. The galley proofs arrived on the plane with Conrad and Ginsburg when they visited Great Slave Lake that summer.

Their visit was both a reunion with Conrad and a farewell. Conrad and I had another trait in common I haven't mentioned - a distaste for mathematics. We shared a belief that with so many exciting things to do which we were good at, a lengthy struggle to gain base-level proficiency in a skill we had little need for seemed a poor investment. Unfortunately for Conrad, the oceanography department included physical oceanographers, whereas the geology department (at that time) had no geophysicist (nor had McMaster). I had passed my orals, on the second try, because my co-advisor and geology chairman Francis Pettijohn, as well as his predecessor Ernst Cloos, had risked a schism in the department on my behalf. Conrad was not so lucky. I never understood why Ginsburg didn't allow Conrad to transfer over into geology. Perhaps it was because delicate negotiations were already underway to unite geology and geophysical fluid mechanics in a new department of Earth and Planetary Sciences (Pettijohn 1988). Perhaps it was because the Ginsburgs already sensed how much they missed south Florida, that their stay in Baltimore would not be for long. Perhaps he thought that the move to Brown University (Providence, Rhode Island) would be good for Conrad. My preferred explanation is that a transfer to geology was offered and Conrad chose to go to Brown on its merits. In 1967, the arrival of oceanographer John Imbrie made Brown better positioned for the future (e.g. Hays et al. 1976) than was Hopkins.

With no Precambrian field work scheduled, 1968 was my opportu- 


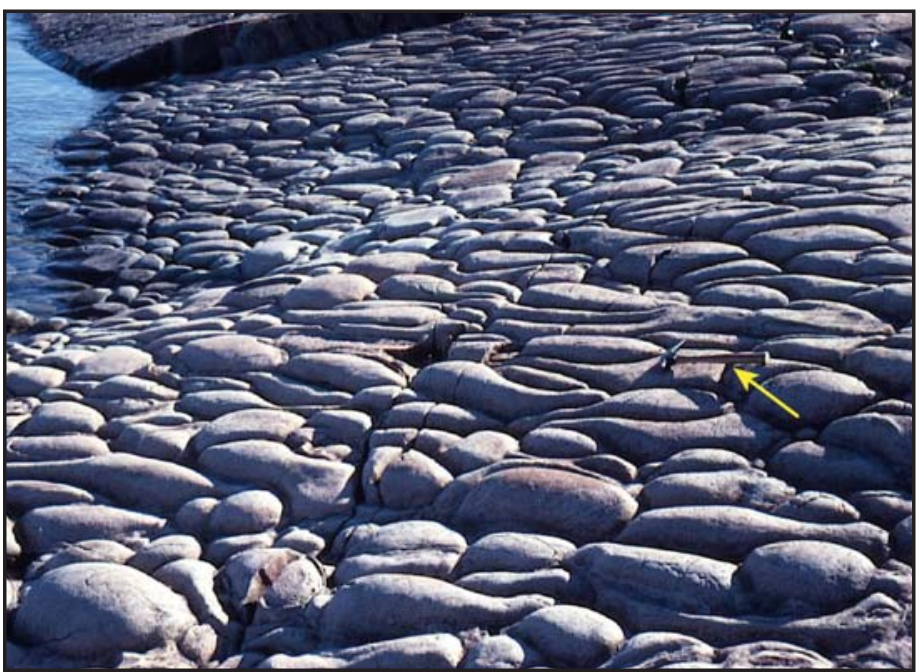

Figure 6. Synoptic morphology of $\sim 1.87-G$ a columnar stromatolites in the Pethei Group, Utsingi Point, Christie Bay, Great Slave Lake. A glaciated bedding-parallel surface has spalled parallel to the internal stromatolitic lamination. The elongation direction is parallel to paleocurrents determined from current ripples and perpendicular to the major platform-to-basin facies zones (Hoffman 1974, 1989). The surface is in the upper part of an unbroken 15-m-thick stromatolite biostrome at the top of the Taltheilei Formation. View looks southwest; hammer (arrow) for scale.

nity to compare modern shallow-water carbonates beyond south Florida and measure stromatolite accretion rates in other settings. Conrad had shown during the previous summer that laminacouplets in sublittoral stromatolites of the Bermuda Islands are strictly diurnal, not tidal, sediment-rich layers accreting in daylight and organic-rich ones at night (Gebelein 1969). My first stop was the northwest coast of Andros Island (Fig. 8), where Ginsburg and colleagues Lawrie Hardy and Owen Bricker were beginning a fouryear study of sedimentation in the tidal-channel belt and adjacent supratidal "algal" marsh (Shinn et al. 1969; Hardie 1977; Monty and Hardie 1977). Like South Florida, microbial mats were limited to the upper intertidal and supratidal zones. Mapping showed this to result from grazing below mean tide level by snails (Fig. 9), rendering most modern tidal flats poor analogs for peritidal carbonates deposited before animals evolved (Garrett 1970). The supratidal marshes, flooded by rainwater in summer, are carpeted by variably-calcified "pincushions" of tufted filamentous cyanobacteria (Fig. 10). I erroneously compared this facies with
Precambrian "microdigitate" stromatolites (Hoffman 1975), a forced modern-ancient comparison. John Grotzinger later demonstrated petrographically that most microdigitate stromatolites are actually sea-floor cements, composed of pseudomorphosed aragonite crystal-fans, a major Precambrian carbonate facies not represented in the modern (Grotzinger and Read 1983; Grotzinger and Knoll 1995). Understanding the Holocene dynamics of the Andros tidal-channel belt would require intensive coring and dating (e.g. Maloof and Grotzinger 2012).

Flying halfway round the world was easier in 1968 than today: landings and walks were obligatory every five or six hours for refueling. I had plenty of time to read up on Shark Bay between Andros Town and Perth. From Logan's work, I knew that grazing by snails would not be a problem in Hamelin Pool (Fig. 11), where restricted circulation due to seagrass banks and strong net evaporation drive salinities up to nearly twice normal seawater, above the tolerance of cerithid gastropods and all but one molluscan species, the button-size pelecypod
Fragum erugatum, which lives in such extraordinary abundance that sawed blocks of Fragum coquina (both eolian and shoreface) were used to build the pub in Denham. In the absence of grazing by snails, microbial mats colonize the lower intertidal zone, subject to the action of refracted waves. In contrast, grazing by snails prevents mat formation in the lower intertidal zone of the metahaline parts of Shark Bay, outside Hamelin Pool, where no highrelief stromatolites occur. In summer, Shark Bay experiences sustained galeforce southerly winds (Fig. 11), which suppress tides and create wave-dominated coastal sand flats, unlike the tidedominated mud flats of Lake Ingraham and western Andros Island. Highrelief circular (Fig. 12) and seawardseeking elongate stromatolites (Fig. 13) are found on exposed headlands and unprotected bights, respectively, on the east side of Hamelin Pool (Fig. 11). Early cementation by cryptocrystalline aragonite provides lithified crusts on which the microbial mats become established; early cementation makes even the high-relief microbial structures wave resistant.

The first "algal reef" was discovered near Flagpole Landing in Hamelin Pool (Fig. 11) in January 1955 by Richard L. (Dick) Chase, a Universi- 


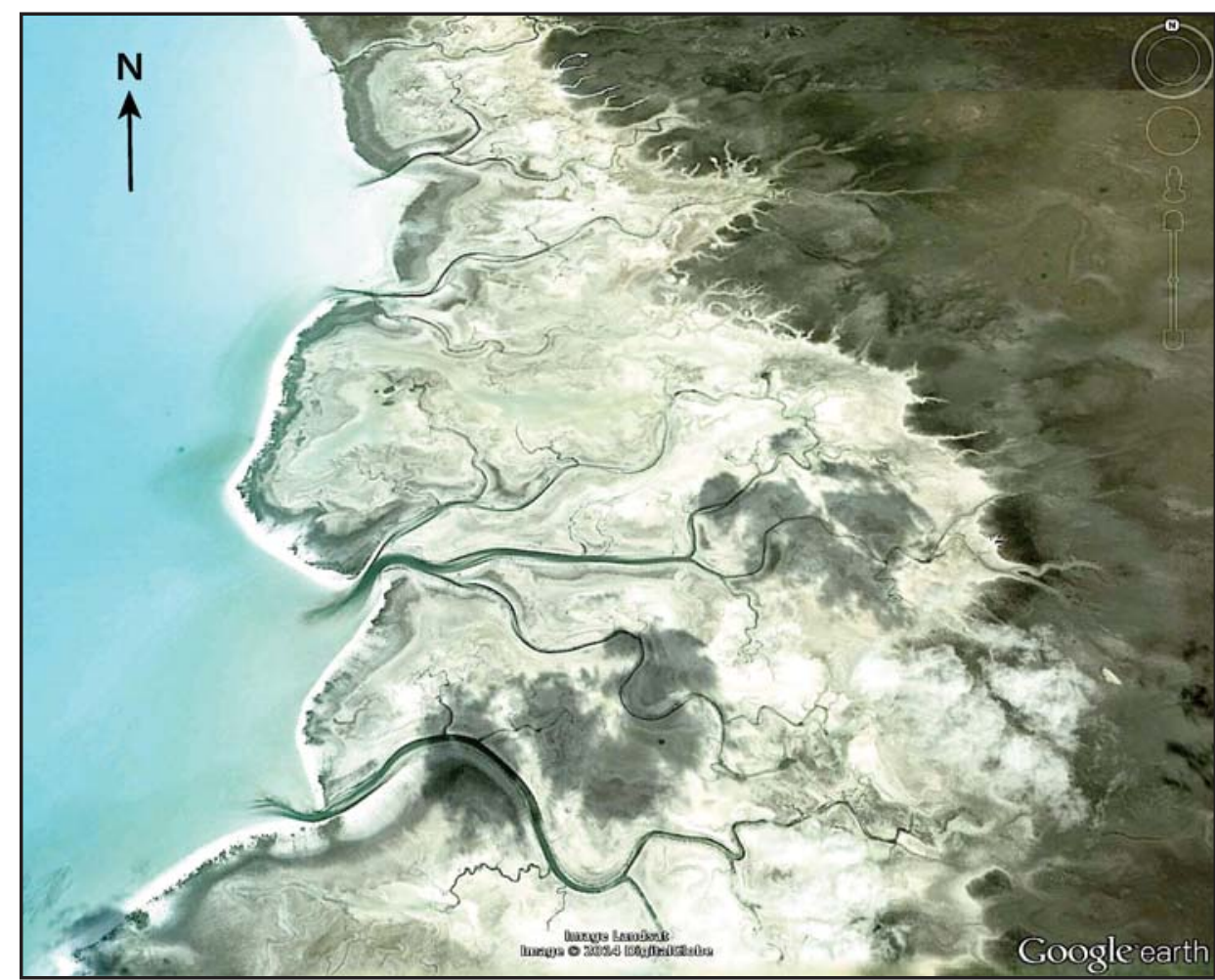

Figure 8. Oblique satellite image of the Loggerhead Point (Triple Goose Creek) area (Shinn et al. 1969; Hardie 1977; Maloof and Grotzinger 2012), northwest Andros Island, Bahamas. On the left in blue is the shallow sublittoral platform of the Great Bahama Bank. In the center is the belt of tidal channels (dark green) with levees (grey), colonized by microbial mats, and ponds (white), in which mats are not developed due to grazing by cerithid gastropods (Fig. 9). Irregular grey splotches in the center foreground are cloud shadows. On the right is the supratidal and seasonally freshwater "algal" marsh (Fig. 10). The prominent creek in the center of the image was informally named Triple Goose Creek by R.N. Ginsburg, for three Grumman G-21("Goose") seaplanes that moored there on field trips. The middleground is $\sim 12 \mathrm{~km}$ wide.

ty of Western Australia (UWA) undergraduate working for Wapet (West Australian Petroleum) as an assistant to Phillip E. (Phil) Playford. Chase had seen ancient stromatolites on a class field trip to the Moora Group (Mesoproterozoic) led by Rhodes Fairbridge. The next year, Chase and Brian Logan did a joint Honours thesis (Logan and Chase 1961) on the Moora Group, which dips off the Yilgarn craton along the Darling Escarpment, north of Perth. Dick Chase went off to Princeton University for his $\mathrm{PhD}$ and has been professor (now emeritus) of marine geology at UBC Vancouver since the advent of plate tectonics. Logan went on to do his $\mathrm{PhD}$ on the geology of Shark Bay, after which he conducted a major study of modern carbonate sediments and reefs on the Yucatán Shelf of eastern Mexico
(Logan et al. 1969), while at Texas A\&M. He had returned to UWA to mount a research program in carbonate sedimentology, ecology and diagenesis, in and around Shark Bay (Logan et al. 1970, 1974; Logan 1987). Among his $\mathrm{PhD}$ students at the time of my visit were Graham Davies and Fred Read, who would achieve notable success in North America as industry and academic carbonate sedimentologists, respectively. My job was to describe the basic microbial mat zonation and stromatolite morphotypes on the east side of Hamelin Pool (Hoffman 1976), collect samples for taxonomic study by Conrad at Brown (Logan et al. 1974), and carry out stromatolite accretion rate studies. "Blue-green algal" (cyanobacterial) taxonomy was in a continual state of flux (Golubiç 1976b). The study was limited to a sin- gle season and time of year (winter), but it would set a basemark for later work (e.g. Playford 1980; Golubiç 1985; Burne and Moore 1987; Reid et al. 2003; Burne and Johnson 2012; Jahnert and Collins 2013). Conrad had trained me well.

Trading summer in the Bahamas for winter in Perth, Western Australia, was shocking and after two weeks at the University of Western Australia, I was glad to turn my face toward the Sun and head northward for two months alone in Shark Bay. Logan's approach to modern carbonate sedimentation impressed me greatly. He embraced the dynamic stratigraphic implications of Quaternary and Holocene base-level changes. He was particularly obsessed by a mysterious 1-2 m late Holocene ( $<5 \mathrm{kyr}$ ) baselevel fall, evidence for which occurs widely on the coast of Western Australia and elsewhere around the Indian Ocean (Fairbridge 1961). The much photographed stromatolites around Carbla Point are largely inactive through Recent emergence and desiccation (Fig. 12). The cause of the relative sea-level fall was then unknown: if eustatic, it implied net growth of polar ice sheets nearly equivalent to a second West Antarctic Ice Sheet. Two probable explanations were subsequently conceived and quantitatively investigated in numerical simulations. The first is that the slow collapse of flexural bulges peripheral to the Laurentide and Scandinavian ice sheets syphoned water from the tropical ocean to fill the subsiding boreal areas of the seafloor (Mitrovica and Peltier 1991). The second is that the addition of a global average $\sim 125$ m of meltwater during the last deglaciation caused isostatic subsidence of the seafloor and consequent upward levering of all continental margins (Mitrovica and Milne 2002).

The obvious fact of coastal emergence in Hamelin Pool turned my attention seaward, where on calm days at low tide I could see rows of ghostly free-standing structures on the sublittoral platform off Carbla Point, at depths of a meter or more at low spring tide. I had a diving mask, snorkle and underwater camera, but no wet suit, having been advised not to swim alone because of sea snakes. Dead ones were washed up on the 


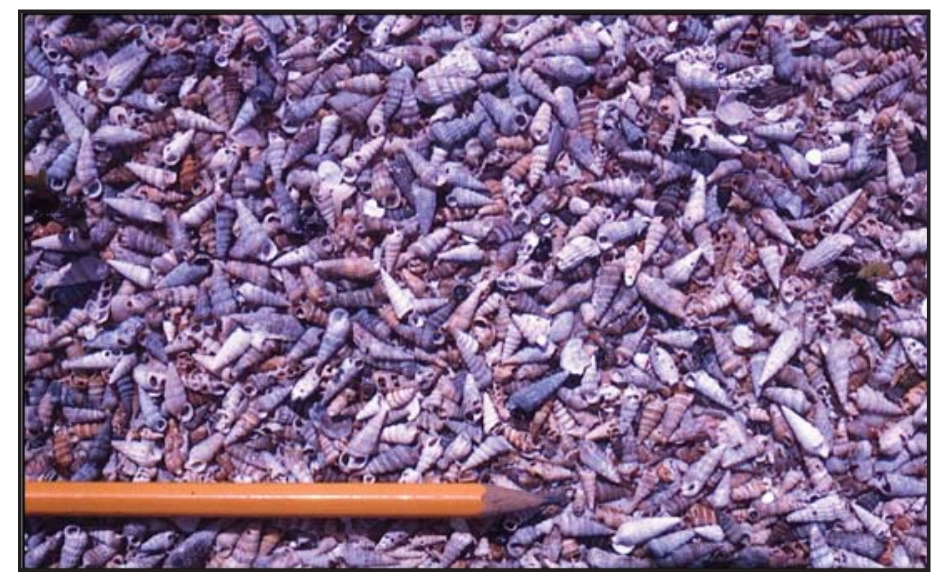

Figure 9. Cerithid gastropod shell lag in the intertidal zone on Andros Island, Bahamas. Grazing by these snails effectively limits microbial mat development on modern marine tidal flats to the upper intertidal and supratidal zones (Garett 1970), excepting hypersaline areas like Hamelin Pool (Fig. 11) uninhabitable by gastropods.

beaches, but I never saw a live one in the water, expecting that like freshwater snakes they would swim at the surface. I later learned that sea snakes hug the bottom in coastal waters and often swim in schools. Their bites are usually painless and no symptoms appear for hours, after which progressive paralysis, renal failure and cardiac arrest may occur. The West Australian Current makes Shark Bay waters painfully cold in July, but I was too dazzled by my first dive to care. Freestanding columnar stromatolites and stromatolite clusters, some with branches, rose up to a meter above the wave-rippled sand (Fig. 14). Given the water depth, their tips were never exposed at low spring tide. They had a distinctive colloform surface morphology and a glistening epiflora of Acetabularia, a macroscopic green alga, accounts for their ghostly appearance. In the excitement of taking photographs and samples underwater, I lost track of time. Back in my tent on the beach, I was barely able to start the Optimus to heat some soup, before retreating into my sleeping bag and shivering uncontrollably for hours. Driving back to Perth, I recalled that some intertidal stromatolites in Hamelin Pool had colloformlike interior structure. I began to wonder if they had originated in the shallow sublittoral and became intertidal during the mysterious late Holocene regression. I anticipated that Logan would be excited by the new develop-

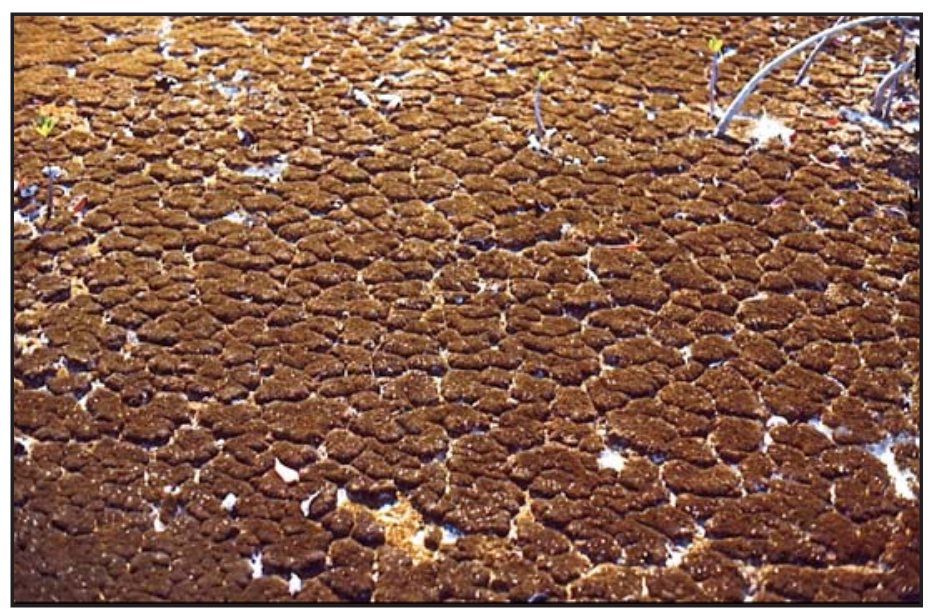

Figure 10. "Pincushions" of the tufted filamentous cyanobacterium Scytonema, characteristic of the supratidal marshes on the west side of Andros Island (Black 1933; Hardie 1977; Monty and Hardie 1977). The cushions are mostly $5-10 \mathrm{~cm}$ in diameter (note mangrove roots) and are intermittently flooded in summer by rainwater. Sediment beneath the surface is well-laminated and partially lithified, with upstanding filament moulds. This semi-arid supratidal facies contasts with the evaporitic supratidal facies of Shark Bay (Fig. 11) and the Trucial Coast (Fig. 14).

ment, but instead it made him gloomy. He insisted that the sublittoral stromatolites were relict intertidal structures formed during early Holocene transgression. He seemed wedded to the idea that stromatolites were strictly intertidal in origin. I thought an early Holocene age for the sublittoral stromatolites was far-fetched and, although Conrad's marking technique was not so successful underwater, I had marked some of them for growth rate study. I owed my entire Shark Bay experience to Logan, so I let the matter drop.

The existence of sublittoral stromatolites in Hamelin Pool would not remain secret for long. Within weeks of my departure, Phil Playford and Tony Cockbain of the Geological Survey of Western Australia found smaller but otherwise homologous stromatolites on the sublittoral platform off Flagpole Landing (Playford and Cockbain 1976; Playford et al. 2013). Later, the full extent of sublittoral stromatolites in Hamelin Pool, ten times the area of intertidal forms, would be documented as would their active sublittoral growth (Jahnert and Collins 2011, 2012). Playford and Logan had a difficult relationship. Dick Chase had been working for Phil when the Hamelin Pool stromatolites were first discovered. Playford had suggested Shark Bay as a thesis area for Logan (encouraged presumably also by Dick Chase) and he retained an active interest in the area, although his primary focus was on the Devonian reef complexes of the Canning Basin (Playford and Lowry 1966, Playford et al. 2009), work which established his international reputation. Playford had the ability to describe complex relationships in simple terms. Too simple for Brian, who sternly insisted that readers be impressed by real complexity. When I submitted a draft manuscript to Logan, it would come back three times longer. Brian clearly resented what he considered Phil's interference, if not proprietary interest, in Shark Bay.

A short while after my visit, Logan came under the influence of sedimentologist Victor Semeniuk, newly arrived from Adelaide. Brian, whose experience with ancient carbonates was limited, came to believe that many so-called "primary" structures are actually products of dissolution (stylolitization) and other burial-diagenetic and metamorphic alterations. He even went so far as to disavow the excellent work on ancient carbonates of his own students (e.g. Read 1973). He published a major critique of Play- 


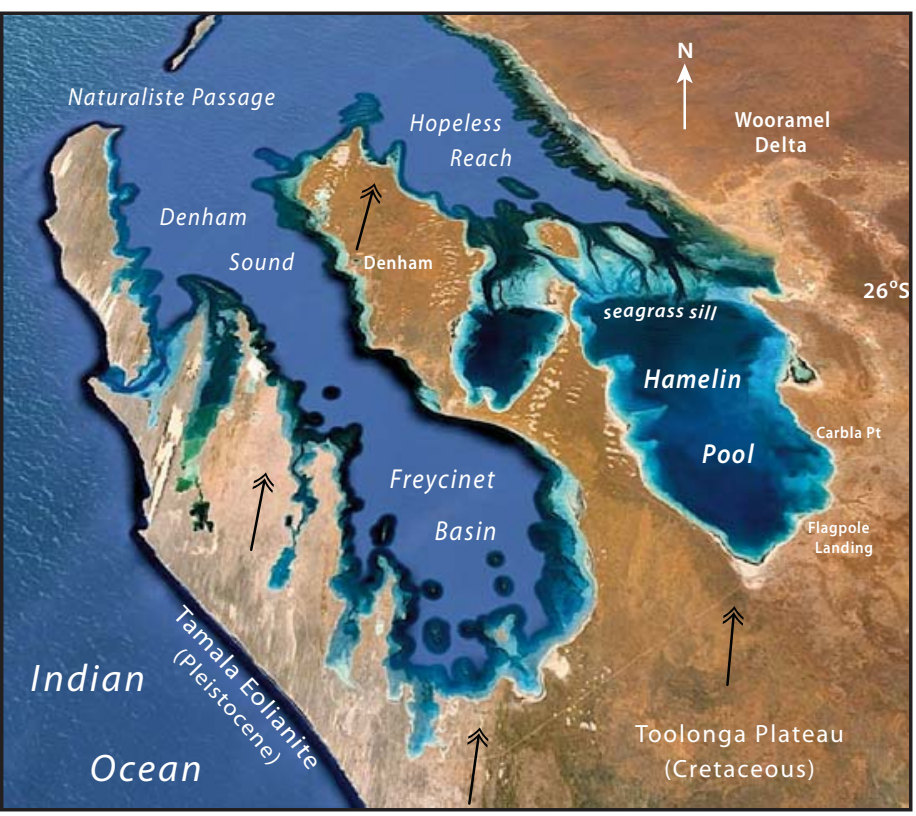

Figure 11. Oblique satellite image of Shark Bay, Western Australia. Net evaporation, restricted circulation due to seagrass sills, and persistent southerly gales in summer (black arrows) cause hypersalinity $(<65 \%$ ) in Hamelin Pool and metahaline conditions $(<50 \%$ ) in Freycinet Basin and Hopeless Reach. Note blowouts in the coastal Pleistocene eolian limestone (Edel Land). Hypersalinity excludes grazing by snails in Hamelin Pool, allowing microbial mats and stromatolites to develop on wave-dominated lower intertidal sand flats and shallow sublittoral platforms.

ford's Devonian reef complex model (Playford and Lowrie 1966), claiming that the entire forereef - reef - backreef zonation and geometry in the Canning Basin are products of stylolitization and related postdepositional processes (Logan and Semeniuk 1976). Brian's career never fully recovered from this débacle, nor did he ever relinquish the view that primary structures are rarely preserved in ancient carbonates.

Flying from Perth to the Trucial Coast (now United Arab Emirates) in early August was a reverse climate shock. August is the hottest month of the year on the Trucial Coast and a gentle onshore wind maintains high humidity to go along with $42^{\circ} \mathrm{C}$

$\left(109^{\circ} \mathrm{F}\right)$ daily high temperatures in $\mathrm{Abu}$ Dhabi, hotter inland. David Kinsman's crew bunked in a trailer in the Industrial Area-residential areas for citizens (Bedouin), commercial workers (South Asian), manual labourers (East African) and minority westerners were strictly segregated. Even then, Aramco (Arabian-American Oil Company) and geo- logical circumstance gave Abu Dhabi citizens the world's highest average earnings. When BOAC flights arrived from London, they would dip their wing toward the Royal Palace before landing. Kinsman, who was centrally interested in sabka evaporites, had been working on the Trucial Coast since the early 1960's, a senior protégé of Doug Shearman (Imperial College London), who gave a spellbinding short-course on evaporite petrography in Calgary, hosted by the Alberta Society of Petroleum Geologists, in 1970. The daily routine in Abu Dhabi was to get up in the middle of the night, drive out of the city to a marked spot on the sabkha, and walk seaward across the tidal flats before first light 5:20 am. Conditions were quite pleasant until 7:30 am, after which our voices got progressively lower and slower until 9:30 am, when we start walking slowly back across the flats. Entering the trailer at midday, where the temperature was maintained at $35^{\circ} \mathrm{C}\left(95^{\circ} \mathrm{F}\right)$, was like walking into a fridge.

Unlike the confines of Cape
Sable and Hamelin Pool, the vast scale of the coastal sabkha and adajcent "algal" flats (Kinsman 1964; Kendall and Skipwith 1968; Purser and Evans 1973; Kinsman and Park 1976) is more comparable to the Pethei Group of Great Slave Lake. The CambroOrdovician carbonate bank encircling Laurentia has no modern counterpart. Microbial mats are mainly developed above mean sea-level, limited by cerithid gastropod grazing. No highrelief (lower intertidal) stromatolites occur. The mats are best developed in upper intertidal ponds, despite being too hot to wade across by late morning. The supratidal zone is a desolate salt crust (sabkha), overlying windblown sediment in which nodular anhydrite precipitates by evaporative pumping (Fig. 15). Given the gypsiferous supratidal of Shark Bay, the occurrence of anhydrite on the Trucial Coast was consistent with Lawrie Hardie's experimentally-determined gypsum-anhydrite equilibrium temperatures (Hardie 1967), a potential paleoclimate proxy. Since the early Holocene transgression, the Abu Dhabi tidal flats have prograded seaward at a rate of nearly $1.0 \mathrm{~m}$ per year, hastened by late Holocene base-level fall of $1.2 \pm 0.1 \mathrm{~m}$ (Kinsman and Park 1976). A few years ago, I went to Google Earth for imagery of the tidal flats I saw with Kinsman outside Abu Dhabi. They are totally obliterated by condominium developments, roadways and jetties. 


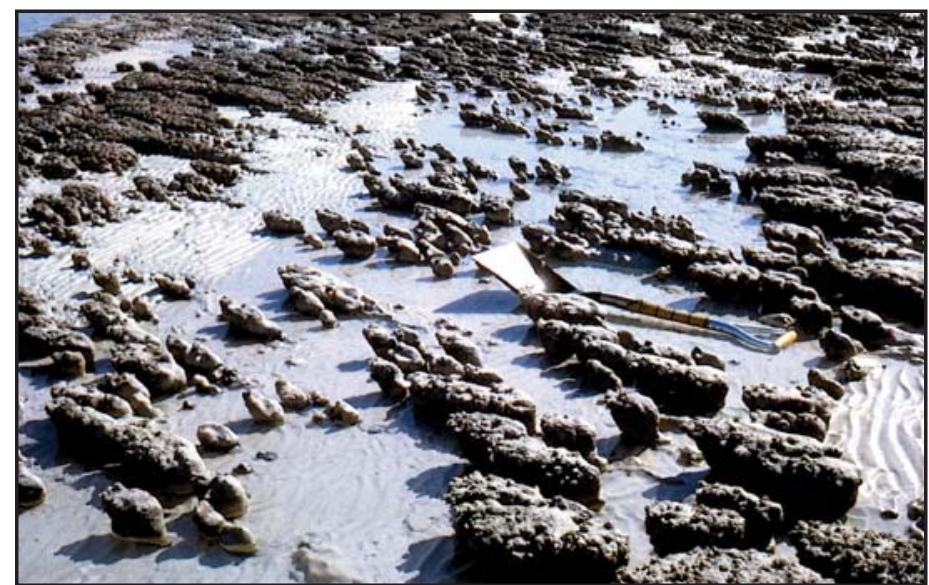

Figure 13. Seaward-tilted columnar stromatolites and rippled ooid-foram sand in the lower intertidal zone of the bight south of Carbla Point (Fig. 11). Stromatolite inclination is due to a combination of excess accretion and basal ablation in the off-shore direction. Elongate stromatolites (parallel to shovel handle) are oriented parallel to wave scour (normal to the strandline) but occur in rows (upper left) that parallel the shoreline. The same geometry is observed in the Pethei Group (1.87 Ga), Great Slave Lake.

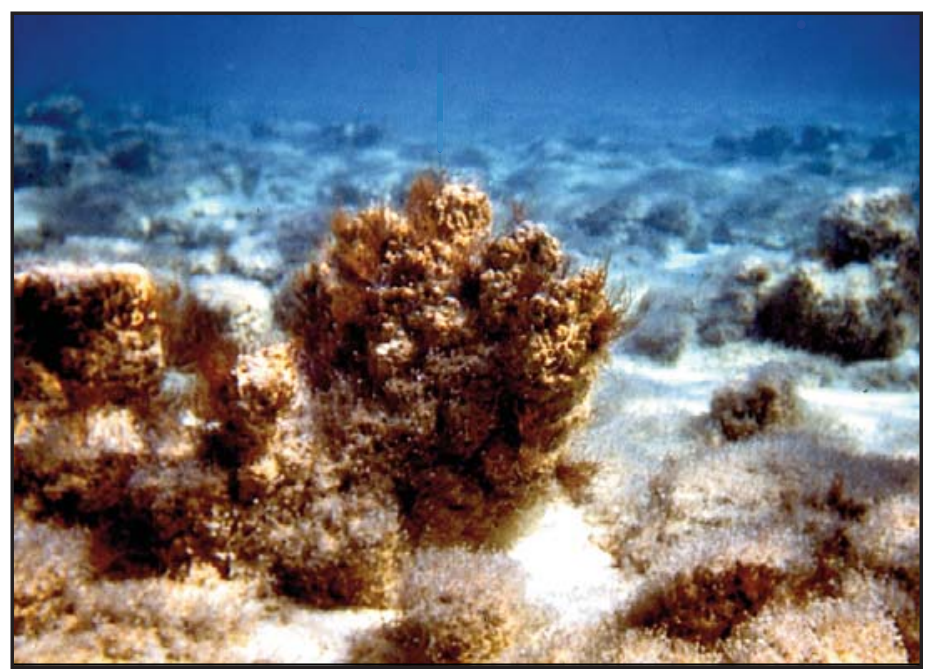

Figure 14. Branching stromatolites $\sim 2.5 \mathrm{~m}$ below mean sealevel on the sublittoral platform at Carbla Point (Fig. 11). The structure in the foreground has $\sim 0.4 \mathrm{~m}$ of relief and is never subaerially exposed. The epiflora is dominated by glistening capped-stalks and hairs of the macroscopic green alga, Acetabularia.

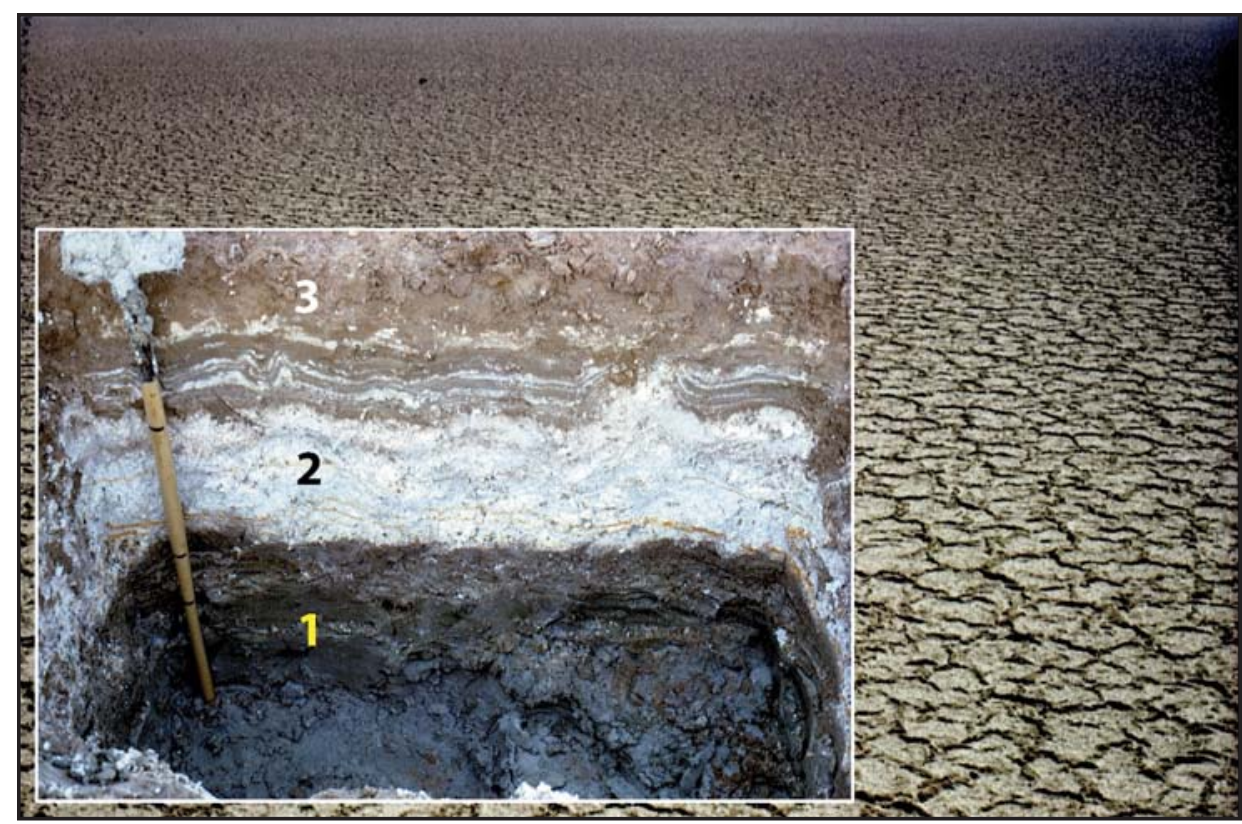

Figure 15. Coastal sabkha (supratidal salt flat) bordering Khor al Bazam, Abu Dhabi (UAE). Inset shows meter-deep trench wall exposing a regressive Holocene sequence: (1) organic-rich microbial mud deposited in upper intertidal ponds, (2) nodular "chicken-wire" anhydrite precipitated in the vadose zone from marine groundwater pumped landward by net evaporation, (3) windblown supratidal silt and fine-grained sand. Tidal flats in the area have prograded seaward $<10 \mathrm{~km}$ in the Holocene, hastened by late Holocene base-level fall (see text). Spade for scale.

A week late for the start of classes, I returned to North America and moved my belongings to Lancaster, Pennsylvania, armed to teach comparative modern-ancient sedimentology at Franklin and Marshall College, while writing up my thesis chapters directly for publication (then innovative, now routine). I delivered the biological samples to Conrad and reported that stromatolite growth rates at Shark Bay were slow - the red markings were still clearly visible when I left. Subsequent work supported Logan's interpretation that the lamination is basically seasonal, with grainy layers (ooids and forams) accreted during winter high tides and micritic layers produced during wind-driven summer lowstands, through textural obliteration of preexisting grains by microbial enterolithic boring and precipitation of void-filling microcrystalline aragonite (Chivas et al. 1990; Reid et al. 2003; Burne and Johnson 2012; Jahnert and Collins 2012). Stromatolite lamination-tidal at Cape Sable, diurnal in Bermuda and annual at Shark Bay-was not a reliable clock. Nevertheless, measured stromatolite accretion rates were geologically swift, raising interesting questions regarding the pair of 15-m-thick columnar stromatolite beds in the Pethei Group of Great Slave Lake (Hoffman 1974; Sami and James 1994).

Conrad described the biological make-up of my seven basic mat types (Hoffman 1976) from the small samples I brought back in my check luggage_- "No, officer, they are not soil samples." Each mat type represents a complex consortium of microbial taxa, but each is dominated by a small number of characteristic cyanobacteria. Allowing for the fluidity of taxonomic nomenclature, Conrad's identifications and characterizations of the basic mat 
types stood up well under subsequent scrutiny (Golubiç 1976a, 1982, 1985). This was remarkable because the main crate of samples rested at the Port of Philadelphia for two years, while broker's invoices chased me around the continent. It would have made for a fragrant episode of "Storage Wars."

I last saw Conrad in Stony Brook on Long Island, where he had been promoted to associate professor after obtaining his $\mathrm{PhD}$ from Brown in 1971. I met his wife, Nancy Maynard, their daughter Jennifer, then an infant, and their semi-domesticated pet crow, Corvus. Conrad later served as assistant director at the Bermuda Biological Station before being appointed associate professor at UCSB (University of California, Santa Barbara), in 1974 at the young age of 28 (Fig. 16). He obtained funding and began a longterm ecology-sedimentology research program on the unstudied and remote southwest coast of Andros Island, where the tidal-channel belt is far wider than in the classic Triple Goose Creek area (Fig. 8) to the north (Gebelein 1974). He had long had his eye on this area. I was teaching at the University of Texas near Dallas in early 1978 when I heard that Conrad had unexpectedly died under mysterious circumstances in the Bahamas. Conflicting stories circulated about the cause of his death, some suggesting homicide. I won't add to them here. Last year at the GSA Annual Meeting in Denver, I ran into Dave Pierce, who was the imaging technician in Preston Cloud's Geobiology Lab at UCSB when I was a lecturer there, three years before Conrad arrived. After the meeting, it occurred to me to ask Dave if he had any knowledge about what had happened to Conrad. Indeed he did. He knew Conrad well and they were working to have Dave admitted as Conrad's graduate student. While conducting research on Andros, Conrad took time off to work on a water project in Haiti, where he contracted meningitis (undiagnosed). Feeling ill, he returned to the Bahamas but died in a hotel room before reaching his research station. No coroner, mindful of the tourist industry, would wish to

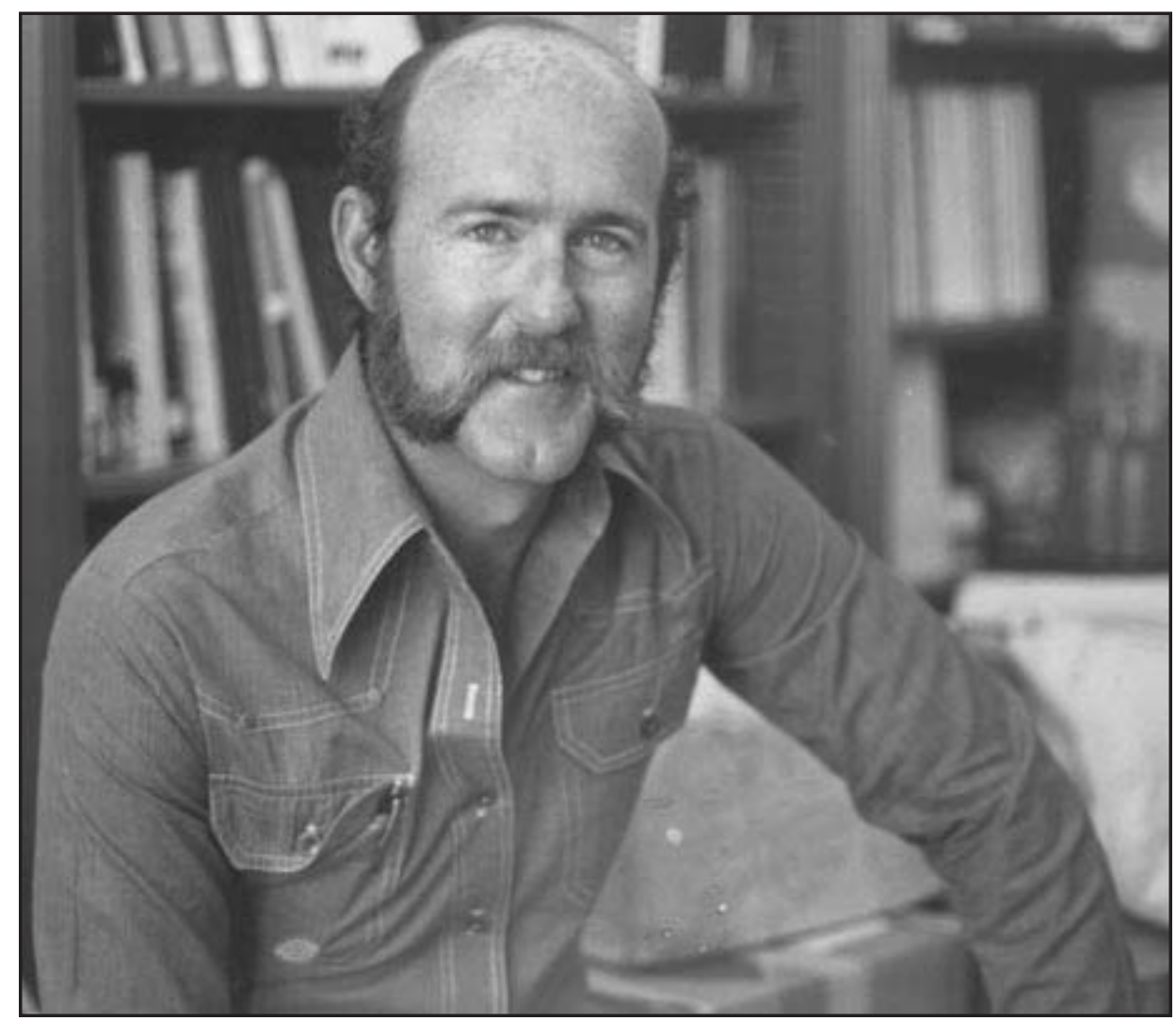

Figure 16. Conrad Gebelein (1945-1978) in Santa Barbara, California, around 1975.

see "meningitis" on a Bahamian death certificate, so what happened after the autopsy is anyone's guess. For Conrad's parents, family, colleagues and friends, he left a hole that time would never completely infill.

Today, geobiologist Tanja

Bosak (Massachusetts Institute of Technology) has taken the experimental approach to stromatolite genesis to a new level-she grows them in the lab. The results are provocative and timely. On the one hand, she has grown ordinary stromatolites with metabolically-ancient, anoxygenic bacterial phototrophs, proving that stromatolites per se are not diagnostic of cyanobacteria (Bosak et al. 2007). On the other hand, she has replicated the disturbed apical zone characteristic of certain conical stromatolites (Conophyton) by the inflation and bursting of bubbles of dioxygen, produced strictly by cyanobacteria (Bosak et al. 2009, 2010). The significance of this discovery for the problematic origin of oxygenic photosynthesis now depends on the range of Conophyton in the Archean stratigraphic record.

\section{REFERENCES}

Black, M., 1933, The algal sediments of Andros Island, Bahamas: Philosophical Transactions of the Royal Society, London, ser. B, v. 222, p. 165-192.

Bosak, T., Greene, S.E., and Newman, D.K., 2007, A likely role for anoxygenic photosynthetic microbes in the formation of ancient stromatolites: Geobiology, v. 5, p. 119-126, http://dx.doi.org/10.1111/j.14724669.2007.00104.x.

Bosak, T., Liang Biqing, Sim Min-Sub, and Petroff, A.P., 2009, Morphological record of oxygenic photosynthesis in conical stromatolites: Proceedings of the National Academy of Sciences (USA), v. 106, p. 10939-10943, http://dx.doi.org/10.1073/pnas.09008 85106.

Bosak, T., Bush, J.W.M., Flynn, M.R., Liang, B., Ono, S., Petroff, A.P., and Sim, M.S., 2010, Formation and stability of oxygen-rich bubbles that shape photosynthetic mats: Geobiology, v. 8, p. 45-55, http://dx.doi.org/ 10.1111/j.1472-4669.2009.00227.x.

Bradley, W.H., 1929, Algae reefs and oolites of the Green River formation: United States Geological Survey, Professional Papers, 154, p. 165-192.

Burne, R.V., and Johnson, K., 2012, Sealevel variation and the zonation of 
microbialites in Hamelin Pool, Shark Bay, Western Australia: Marine and Freshwater Research, v. 63, p. 994-1004, http://dx.doi.org/10.1071/MF12184.

Burne, R.V., and Moore, L.S., 1987, Microbialites: Organosedimentary deposits of benthic microbial communities: Palaios, v. 2, p. 241-254, http://dx.doi.org/10.2307/3514674.

Chivas, A.R., Torgersen, T., and Polach, H.A., 1990, Growth rates and Holocene development of stromatolites from Shark Bay, Western Australia: Australian Journal of Earth Sciences, v. 37, p. 113-121, http://dx.doi.org/10.1080/081200990 08727913.

Dorr, F.W., 1857, Report to the Superintendent of the United States Coast Survey: United States Coast Survey, Executive Documents, 33, p. 383-387.

Fairbridge, R.W., 1961, Eustatic changes in sea level, in Physics and Chemistry of the Earth, v. 4: Pergamon Press, New York, p. 99-185.

Garrett, P., 1970, Phanerozoic stromatolites: Noncompetitive ecologic restriction by grazing and burrowing animals: Science, v. 169, p. 171-173, http://dx.doi.org/10.1126/science.169.3941.171.

Gebelein, C.D., 1969, Distribution, morphology and accretion rate of recent subtidal algal stromatolites, Bermuda: Journal of Sedimentary Petrology, v. 39, p. 46-69.

Gebelein, C.D., 1974, Guidebook for modern Bahamian platform environments: Geological Society of America, Annual Meeting, 1974, Field Trip Guidebooks, $97 \mathrm{p}$.

Gebelein, C.D., 1977, Dynamics of Recent Carbonate Sedimentation and Ecology, Cape Sable, Florida: E.J. Brill, Leiden, 120 p., 52 figs., 8 plates.

Ginsburg, R.N., 1955, Recent stromatolitic sediments from south Florida (abstract): Journal of Paleontology, v. 29, p. 723-724.

Golubiç, S., 1976a, Organisms that build stromatolites, in Walter, M.R., ed., Developments in Sedimentology: Stromatolites: Elsevier, Amsterdam, v. 20p. 113-126, http://dx.doi.org/ 10.1016/S0070-4571(08)71132-4.

Golubiç, S., 1976b, Taxonomy of extant stromatolite-building cyanophytes, in Walter, M.R., ed., Developments in Sedimentology: Stromatolites: Elsevier, Amsterdam, v. 20, p. 127-140, http://dx.doi.org/10.1016/S00704571(08)71133-6.

Golubiç, S., 1982, Microbial ecology of algal mats and recent stromatolites in
Shark Bay, Western Australia: National Geographic Society, Research Reports, v. 14 , p. $277-286$

Golubiç, S., 1985, Microbial mats and modern stromatolites in Shark Bay, Western Australia, in Caldwell, D.E., Brierley, J.A., and Brierley, C.L., eds., Planetary Ecology: Van Norstrand Reinhold Co., New York, p. 3-16.

Grotzinger, J.P., and Knoll, A.H., 1995, Anomalous carbonate precipitates: Is the Precambrian the key to the Permian?: Palaios, v. 10 , p. $578-596$, http://dx.doi.org/10.2307/3515096.

Grotzinger, J.P., and Read, J.F., 1983, Evidence for primary aragonite precipitation, lower Proterozoic (1.9 Ga) Rocknest dolomite, Wopmay orogen, northwest Canada: Geology, v. 11, p. 710-713, http:/ /dx.doi.org/ 10.1130/0091-7613(1983)11 $<710$ :EFPAPL>2.0.CO;2.

Hall, J., 1883, Cryptozoon, N. G., and Cryptozoon proliferum n. sp.: New York State Museum, Annual Reports, 36, 6 plates and explanation.

Hardie, L.A., 1967, The gypsum-anhydrite equilibrium at one atmosphere pressure: American Mineralogist, v. 52, p. 171-200.

Hardie, L.A., ed., 1977, Sedimentation on the Modern Carbonate Tidal Flats of Northwest Andros Island, Bahamas: The Johns Hopkins University Press, Baltimore, 202 p.

Hays, J.D., Imbrie, J., and Shackleton, N.J., 1976, Variations in the Earth's orbit: pacemaker of the ice ages: Science, $v$. 194, p. 1121-1132, http:/ /dx.doi.org/ 10.1126/science.194.4270.1121.

Hoffman, P., 1967, Algal stromatolites: use in stratigraphic correlation and paleocurrent determination: Science, v. 157, p. 1043-1045, http://dx.doi.org/ 10.1126/science.157.3792.1043.

Hoffman, P., 1974, Shallow and deepwater stromatolites in lower Proterozoic platform-to-basin facies change, Great Slave Lake, Canada: American Association of Petroleum Geologists Bulletin, v. 58, p. 856-867.

Hoffman, P., 1975, Shoaling-upward shaleto-dolomite cycles in the Rocknest Formation (Lower Proterozoic), Northwest Territories, Canada, in Ginsburg, R.N., ed., Tidal Deposits, a Casebook of Recent Examples and Fossil Counterparts: Springer-Verlag, New York, p. 257-265.

Hoffman, P., 1976, Stromatolite morphogenesis in Shark Bay, Western Australia, in Walter, M.R., ed., Developments in Sedimentology: Stromatolites: Elsevier, Amsterdam, v. 20, p. 261-271, http://dx.doi.org/
10.1016/S0070-4571(08)71139-7.

Hoffman, P.F., 1989, Pethei reef complex (1.9 Ga), Great Slave Lake, N.W.T., in Geldsetzer, H.H., James, N.P., and Tebbutt, G.E., eds., Reefs, Canada and Adjacent Areas: Canadian Society of Petroleum Geologists, Memoirs, 13, p. 38-54.

Jahnert, R.J., and Collins, L.B., 2011, Significance of subtidal microbial deposits in Shark Bay, Australia: Marine Geology, v. 286, p. 106-111, http://dx.doi.org/10.1016/j.margeo.2011.05.006.

Jahnert, R.J., and Collins, L.B., 2012, Characteristics, distribution, and morphogenesis of subtidal microbial systems in Shark Bay, Australia: Marine Geology, v. 303-306, p. 115-136, http://dx.doi.org/10.1016/j.margeo.2012.02.009.

Jahnert, R.J., and Collins, L.B., 2013, Controls on microbial activity and tidal flat evolution in Shark Bay, Western Australia: Sedimentology, v. 60, p. 1071-1099, http://dx.doi.org/10.1111/sed.12023.

Jones, C.B., 1981, Periodicities in stromatolite lamination from the early Proterozoic Hearne Formation, Great Slave Lake, Canada: Palaeontology, v. 24, Part 2, p. 231-250.

Kalkowsky, E., 1908, Oolith und Stromatolith im norddeutschen Bundsandstein: Zeitschrift der Deutschen Geologischen Gesellschaft, v. 60, p. 68-125.

Kendall, C.St.C., and Skipwith, Sir P.A.d'E., Bt., 1968, Recent algal mats of a Persian Gulf lagoon: Journal of Sedimentary Petrology, v. 38, p. 1040-1058.

Kinsman, D.J.J., 1964, The recent carbonate sediments near Halal al Bahrani, Trucial Coast, Persian Gulf, in van Straaten, L.M.J.U., ed., Developments in Sedimentology: Deltaic and Shallow Marine Deposits: Elsevier, Amsterdam, v. 1, p. 189-192, http://dx.doi.org/10.1016/S00704571(08)70485-0.

Kinsman, D.J.J., and Park, R.K., 1976, Algal belt and coastal sabkha evolution, Trucial Coast, Persian Gulf, in Walter, M.R., ed., Developments in Sedimentology: Stromatolites: Elsevier, Amsterdam, v. 20, p. 421-433, http://dx.doi.org/10.1016/S00704571(08)71149-X.

Lausen, C., 1929, A geological reconnaissance of the east end of Great Slave Lake: Bulletin of the Canadian Institute for Mining and Metallurgy, v. 22, no. 209, p. 361-392.

Logan, B.W., 1961, Cryptozoon and associate stromatolites from the Recent, Shark Bay, Western Australia: The Journal of 
Geology, v. 69, p. 517-533, http://dx.doi.org/10.1086/626769.

Logan, B.W., 1987, The McLeod evaporite basin, Western Australia: American Association of Petroleum Geologists, Memoirs, 44, $140 \mathrm{p}$.

Logan, B.W., and Chase, R.L., 1961, The stratigraphy of the Moora Group, Western Australia: Journal and Proceedings of the Royal Society of Western Australia, v. 44, p. 14-32.

Logan, B.W., and Semeniuk, V., 1976, Dynamic metamorphism; processes and products in Devonian carbonate rocks, Canning Basin, Western Australia: Geological Society of Australia, Special Publications, 6, $138 \mathrm{p}$.

Logan, B.W., Rezak, R., and Ginsburg, R.N., 1964, Classification and environmental significance of algal stromatolites: The Journal of Geology, v. 72, p. 68-83, http://dx.doi.org/10.1086/626965.

Logan, B.W., Harding, J.L., Ahr, W.M., Williams, J.D., and Snead, R.G., 1969, Carbonate sediments and reefs, Yucatán Shelf, Mexico: American Association of Petroleum Geologists, Memoirs, 11, p. 1-198.

Logan, B.W., Davies, G.R., Read, J.F., and Cebulski, D.E., 1970, Carbonate sedimentation and environments, Shark Bay, Western Australia: American Association of Petroleum Geologists, Memoirs, 13, Tulsa, Oklahoma, 223 p.

Logan, B.W., Read, J.F., Hagan, G.M., Hoffman, P., Brown, R.G., Woods, P.J., and Gebelein, C.D., 1974, Evolution and Diagenesis of Quaternary Carbonate Sequences, Shark Bay, Western Australia: American Association of Petroleum Geologists, Memoirs, 22, Tulsa, Oklahoma, 358 p.

Maloof, A.C., and Grotzinger, J.P., 2012, The Holocene shallowing-upward parasequence of north-west Andros Island, Bahamas: Sedimentology, v. 59, p. 1375-1407, http://dx.doi.org/ 10.1111/j.1365-3091.2011.01313.x.

Mitrovica, J.X., and Milne, G.A., 2002, On the origin of late Holocene sea-level highstands within equatorial ocean basins: Quaternary Science Reviews, v. 21, p. 2179-2190, http://dx.doi.org/ 10.1016/S0277-3791(02)00080-X.

Mitrovica, J.X., and Peltier, W.R., 1991, On postglacial geoid subsidence over the equatorial oceans: Journal of Geophysical Research, v. 96, p. 20053-20071, http://dx.doi.org/ 10.1029/91JB01284.

Monty, C.L.V., and Hardie, L.A., 1977, The geological significance of the freshwater blue-green algal calcareous marsh, in Walter, M.R., ed., Developments in
Sedimentology: Stromatolites: Elsevier, Amsterdam, v. 20, p. 447-477.

Pannella, G., 1972, Precambrian stromatolites as palaeontological clocks: 24 th International Geological Congress, Montreal, Section 1, p. 50-57.

Pettijohn, F.J., 1988, A Century of Geology 1885-1985 at The Johns Hopkins University: Gateway Press, Baltimore, $316 \mathrm{p}$.

Playford, P.E., 1980, Environmental controls on the morphology of modern stromatolites at Hamelin Pool, Western Australia, in Annual Report for 1979: Geological Survey of Western Australia, p. 73-77.

Playford, P.E., and Cockbain, A.E., 1976, Modern algal stromatolites at Hamelin Pool, a hypersaline barred basin in Shark Bay, Western Australia, in Walter, M.R., ed., Developments in Sedimentology: Stromatolites: Elsevier, Amsterdam, v. 20, p. 389-411, http://dx.doi.org/10.1016/S00704571(08)71147-6.

Playford, P.E., and Lowry, D.C., 1966, Devonian reef complexes of the Canning Basin, Western Australia: Geological Survey of Western Australia, Bulletins, 118,149 p. and supplementary atlas.

Playford, P.E., Hocking, R.M., and Cockbain, A.E., 2009, Devonian reef complexes of the Canning Basin, Western Australia: Geological Survey of Western Australia, Bulletins, 145, 444 p. and 8 full-colour geologic maps, scales 1:500,000 to $1: 25,000$.

Playford, P.E., Cockbain, A.E., Berry, P.F., Roberts, A.P., Haines, P.W., and Brooke, B.P., 2013, The Geology of Shark Bay: Geological Survey of Western Australia, Bulletins, 146, 281 p.

Purser, B.H., and Evans, G., 1973, Regional sedimentation along the Trucial Coast, SE Persian Gulf, in Purser, B.H., ed., The Persian Gulf: Holocene Carbonate Sedimentation and Diagenesis in a Shallow Epicontinental Sea: SpringerVerlag, New York, p. 211-231, http://dx.doi.org/10.1007/978-3-64265545-6_13.

Read, J.F., 1973, Paleo-environments and paleogeography, Pillara Formation (Devonian), Western Australia: Bulletin of Canadian Petroleum Geology, v. 21, p. 344-394.

Reid, R.P., James, N.P., Macintyre, I.G., Dupraz, C.P., and Burne, R.V., 2003, Shark Bay stromatolites: microfabrics and reinterpretation of origins: Facies, v. 49, p. 299-324.

Riding, R., 1999, The term stromatolite: towards an essential definition: Letha- ia, v. 32, p. 321-330,

http://dx.doi.org/10.1111/j.1502-

3931.1999.tb00550.x.

Roddy, H.J., 1915, Concretions in streams formed by the agency of blue-green algae and related plants: American Philosophical Society, Proceedings, v. 54, p. 246-258.

Sami, T.T., and James, N.P., 1994, Peritidal carbonate platform growth and cyclicity in an early Proterozoic foreland basin, upper Pethei Group, northwest Canada: Journal of Sedimentary Research, v. 64, p. 111-131, http://dx.doi.org/10.1306/D4267F6E -2B26-11D7-8648000102C1865D.

Shinn, E.A., Lloyd, R.M., and Ginsburg, R.N., 1969, Anatomy of a modern carbonate tidal-flat, Andros Island, Bahamas: Journal of Sedimentary Research, v. 39, p. 1202-1228, http://dx.doi.org/10.1306/74D71DC F-2B21-11D7-8648000102C1865D.

Stockwell, C.H., 1932, Great Slave Lake Coppermine River area, Northwest Territories, in Annual Report, Part C: Geological Survey of Canada, p. 37-63.

Stockwell, C.H., 1936, Eastern portion of Great Slave Lake: Geological Survey of Canada, Maps, 377A (west half) and $378 \mathrm{~A}$ (east half), scale: 4 miles to one inch.

Tebeau, C.W., 1968, Man in the Everglades: University of Miami Press, Coral Gables, Florida, 192 p.

Walcott, C.D., 1914, Pre-Cambrian Algonkian algal flora: Smithsonian Miscellaneous Collections, v. 64, p. 74-156.

\section{ACKNOWLEGEMENTS}

While these columns have benefited from comments and suggestions of readers too numerous to list by name, a few individuals provided detailed information that was critical for a story's veracity. I am endebted to Alfred Kröner (Mainz), Marcus Kunzmann (Montréal), Roy Miller (Windhoek) and Gabi Schneider (Windhoek) re Henno Martin (v. 40, no. 1); Karin Sigloch (Munich) re the North American Cordillera (v. 40, no. 2); Peter Dawes (Copenhagen) and Tom Frisch (Ottawa) re Lauge Koch (v. 40, no 4), and Bob Burne (Canberra), Dick Chase (Vancouver) and Dave Pierce (Santa Barbara) re Conrad Gebelein (v. 41, no. 2). 